\title{
PENGARUH LINGKUNGAN KERJA DAN KREATIVITAS TERHADAP STRES GURU SMA NEGERI SUB RAYON 1 KOTA BEKASI
}

\author{
Wati Hernawati*
}

\begin{abstract}
The objective of this research was to determine the Effect of Work Environment and Creativity to the Stress of Teacher at Junior High School in Medan Satria Bekasi. The data were collected through participant observation using survey by questionnaires. The data analysis using simple correlation, simple linear regression. Tlie target population size of this research is 236 teachers. Research samples selected as much as 149 teachers using simple random sampling technique.Tlie data obtained analyzed using path analysis technique. Based on this research of data obtained the following conclusions: (1) the work environment have negative direct effect to stress, (2) the creativity have negative direct effect to work stress, (3) the work environment have positive direct effect to creativity.
\end{abstract}

Key words: stress, work environment, creativity

\section{PENDAHULUAN}

Keberhasilan penyelenggaraan pendidikan tidak hanya ditentukan oleh kurikulum, sarana prasarana, biaya atau manajemen semata, namun yang lebih utama adalah oleh pendidik dan tenaga kependidikan yang terlibat didalamnya. Pendidik dalam hal ini adalah guru yang memiliki peran dan pengaruh yang sangat besar bagi kemajuan sekolah sebagai organisasi penyelenggaraan pendidikan. Guru memegang peranan sentral dalam proses pendidikan. Guru dituntut untuk bekerja secara professional untuk mengerahkan segenap kemampuan dalam melaksanakan tugas. Pendidikan merupakan faktor utama dalam pembentukan pribadi manusia. Pendidikan berperan dalam membentuk baik atau buruknya pribadi manusia menurut ukuran normatif. Dalam melaksanakan tugas dan tanggungjawabnya sebagai guru seringkali stres muncul mengiringinya. Adanya tuntutan yang berlebihan tanpa diimbangi dengan peningkatan kesejahteraan, pembagian tugas yang tidak merata antar sesama guru,serta perlakuan dari atasan yang tidak adil dapat menyebabkan timbulnya stress. Konflik antara sesama guru, perbedaan persepsi anggota terhadap tujuan sekolah, pekerjaan yang membutuhkan waktu yang lebih banyak, kurangnya lingkungan kerja dalarn organisasi, lingkungan kerja yang tidak nyaman, dan kondisi tempat kerja menjadi pemicu terjadinya stres.

Komisi D Dewan Perwakilan Rakyat Daerah Kota Bekasi, Jawa Barat menyayangkan terjadinya perseteruan antara guru dan guru SMAN 5 Kota Bekasi yang berimbas terganggunya persiapan siswa menjelang ujian nasional. Anggota Komisi D DPRD Kota Bekasi, Djoko Suyanto mengatakan mutasi guru SMAN 5 menyisakan sejumlah masalah. Secara keseluruhan kurang lebih 60 guru pengajar masih menginginkan kinerja dari guru yang lama, guru-guru masih menolak kehadiran guru baru. Hal ini membuat situasi belajar mengajar tidak kondusif. Bahkan guru yang baru mengintimidasi dan mengancam terhadap guru yang kritis. Intimidasi yang terjadi

\footnotetext{
* Guru SMAN 9 Kota Bekasi
} 
membuat guru resah. Stres yang terjadi pada guru SMAN 5 ini dapat berakibat fatal terhadap kelancaran proses kegiatan belajar mengajar.

Ketua Pengurus Besar Persatuan Guru Republik Indonesia (PBPGRI), Sulistiyo mengatakan, uji kompetensi membuat guru-guru yang ingin mengikuti sertifikasi stres karena dipersulit dengan uji kompetensi untuk melakukan pendaftaran. Di sisi lain, guru yang sudah senior pun merasa malu karena tidak lulus uji kompetensi. Femerintah dinilai sarna sekali tidak mengindahkan waktu lama mengajar para guru senior. Uji kompetensi mengakibatkan guru banyak yang stres karena tidak lulus. Jika guru stress maka akan berdampak pada penurunan mutu pendidikan. Kenyataan tersebut juga terjadi di Kota Bekasi. Di kota bekasi terdapat 2.266 guru yang akan mengikuti UKA. Banyak yang stres dengan keadaan ini sehingga semangat membaca maupun belajar guru menurun.

Melihat uraian di atas, objek terpenting adalah para guru, karena tinggi rendahnya mutu suatu pendidikan tidak terlepas dari peran para guru. Tidak terpenuhi untuk pemenuhan kebutuhan para guru juga penyebab timbulnya stres. Selain itu juga tidak adanya alat kontroling serta evaluasi yang berkelanjutan untuk memantau situasi dan kondisi yang terjadi di lingkungan kerja para guru. Dengan demikian stres akan menjadi masalah yang besar. Stres dapat terjadi bila kebutuhan mereka tidak dapat terpenuhi menurut ukuran dan tingkatan kebutuhan mereka masing-masing. Stres dipengaruhi oleh banyak faktor dan salah satu diantaranya adalah lingkungan kerja. Hal tersebut didasarkan pada asumsi jika para guru menyenangi lingkungan tempat mereka bekerja, maka mereka akan merasa betah bekerja ditempat tersebut. Dengan demikian para guru berusaha memberikan yang terbaik untuk pekerjaannya, sehingga waktu yang ada dapat dipergunakan seoptimal mungkin tanpa banyak membuang waktu dengan hal-hal yang tidak bermanfaat dan optimis prestasi kerja guru menjadi lebih tinggi. Jika dikaitkan dengan mutu pendidikan, stres menjadi satu hal yang penting. Hal lain yang menyangkut stres adalah cara pandang pegawai terhadap pekerjaannya. Hal ini akan memunculkan sikap terhadap pekerjaan dan segala sesuatu yang dihadapi dilingkungan pekerjaannya. Sikap yang muncul ini dapat berwujud positif atau negatif.

Berdasarkan uraian di atas, perlu dikaji faktor-faktor yang dapat mempengaruhi stress guru. Untuk itu peneliti merasa tertarik untuk melakukan penelitian tentang "Pengaruh Lingkungan Kerja dan Kreativitas terhadap Stres Guru SMA Negeri Sub Rayon 1 Kota Bekasi" 


\section{Stres}

McShane (2008:198) menyatakan, "stress is an adaptive response to a situation that is perceived as challenging or threatening to a person's well-being. The stress response is a complex emotion that produces physiological changes to prepare us for "fight or flight" to defend ourselves from the threat or flee from it." Stres adalah merupakan respon atau reaksi berlebihan terhadap situasi yang dianggap sebagai tantangan atau ancaman terhadap kesejahteraan seseorang. Slocum (2007:448) menyatakan stress sebagai, "stress is the excitement, feeling of anxiety, and/or physical tension that occurs when the demands placed on an individual are thought to exceed the person's ability to cope. This most common view of stress is often called distress or negative stress. Stressors are the psychological demands in the environtment that cause this condition." Stres adalah kegembiraan, perasaan kecemasan, atau ketegangan fisik yang terjadi ketika tuntutan ditempatkan pada individu diperkirakan melebihi kemampuan seseorang untuk mengatasi. Pandangan yang paling umum dari stres sering disebut tekanan atau stres negatif. Stressor merupakan tuntutan psikologis dalam suasana yang menyebabkan kondisi ini. Mereka membuat stres atau potensi stres ketika seseorang memandang mereka sebagai mewakili permintaan yang melebihi kemampuan orang itu untuk merespon. Frustasi muncul karena adanya kegagalan saat ingin mencapai suatu hal/tujuan. Misalnya seseorang mengalami kegagalan dalam pekerjaan yang mengakibatkan orang tersebut harus turun jabatan. Orang yang memiliki tujuan tersebut mendapat beberapa rintangan/hambatan yang tidak mampu ia lalui sehingga ia mengalami kegagalan atau frustasi. Konflik juga nerupakan pemicu dari stress . Konflik ditimbulkan karena ketidakmampuan memilih dua atau lebih macam keinginan, kebutuhan, atau tujuan. Saat seseorang dihadapkan dalam situasi yang berat untuk dipilih, orang tersebut akan mengalami konflik dalam dirinya. Tekanan dapat berasal dari dalam diri individu, misalnya cita-cita atau norma yang terlalu tinggi sehingga menimbulkan tekanan dalam diri seseorang. Tekanan juga berasal dari luar diri individu, misalnya orang tua yang menuntut anaknya untuk masuk ke dalam jurusan yang tidak diminati oleh anaknya, anak yang menuntut orang tua untuk dibelikan semua kemauannya, dan lain-lain. Kecemasan merupakan suatu kondisi ketika individu merasakan kekhawatiran/kegelisahan, ketegangan, dan rasa tidak nyaman yang tidak terkendali mengenai kemungkinan akan terjadinya sesuatu yang buruk.

Menurut Robbins (2011:641), "stress is a dynamic condition in which an individual is confronted with an opportunity, demand, or resource related to what the individual desires and for which the outcomes is perceived to be both uncertain and important". Stres adalah suatu kondisi dinamis di mana seorang individu dihadapkan dengan kesempatan, tuntutan, atau sumber daya yang terkait dengan apa keinginan individu dan dimana hasil yang dianggap tidak pasti dan penting.

Kreitner (2008:551) mendefinisikan stres sebagai, "stress ia an adaptive response, mediated by individual characteristics and or psychological processes, that is a consequence of any external action, situation, or event that places special physical and or psychological demands upon a person." Stres adalah merupakan reaksi berlebihan yang sangat besar, dimediasi oleh karakteristik individu dan atau proses psikologis, yang merupakan konsekuensi dari setiap tindakan eksternal, situasi, atau peristiwa yang menempatkan tuntutan fisik 
dan atau psikologis khusus pada seseorang. Jennifer (2012:245) menyatakan, "stress is the experience of opportunities or threats that -people percieve as important and also perceive $t l^{\wedge} e y$ not be able to handle or deal with effectively. Stress can be experienced because of both opportinities and threats." Stres adalah pengalaman peluang atau ancaman bahwa orang melihat sebagai hal yang penting dan juga menganggap mereka tidak mampu menangani atau berurusan dengan efektif. Stres dapat dialami karena baik kesempatan dan ancaman. Jika seorang pegawai tidak mampu menangani masalah dalam pekerjaannya yang membuat pegawai tersebut merasa terancam, maka akan timbullah sebuah tekanan. Tekanan itu menimbulkan gangguan dalam psikologinya. Sehingga ia merasa tidak nyaman dalam bekerja. Stress adalah suatu kondisi dinamik yang didalamnya seorang individu dikonfrontasikan dengan suatu peluang, kendala, atau tuntutan yang dikaitkan dengan apa yang sangat diinginkannya dan yang hasilnya dipresepsikan sebagai tidak pasti dan penting. Stres merupakan faktor fisik, kimiawi, dan emosional yang dapat menyebabkan tekanan pada tubuh atau mental dan dapat menjadi faktor bagi timbulnya penyakit. Stres juga merupakan interaksi individu dengan lingkungan, namun secara lebih terperinci stres merupakan suatu respon adaptif yang dihubungkan oleh perbedaan individu dan atau proses psikologi yang merupakan konsekuensi tindakan, situasi, atau kejadian eksternal (lingkungan) yang menempatkan tuntutan psikologi dan atau fisik secara berlebihan.

Berdasarkan uraian di atas, dapat disintesiskan stres adalah suatu kondisi yang timbul ketika tuntutan pekerjaan melebihi kemampuan dalam melaksanakan pekerjaan tertentu dan interaksinya dengan orang lain yang menyebabkan seseorang tidak nyaman dalam bekerja dengan indikator: reaksi berlebihan terhadap situasi, ketegangan fisik akibat tuntutan kerja, keinginan yang tidak sesuai dengan kondisi yang diharapkan, dan ketidakmampuan menangani masalah.

\section{Lingkungan kerja}

Gibson (2009:413) menyatakan, "environment was conceptualized from the perspective of the organization members as they looked outward". Lingkungan adalah suatu konsep yang memandang setiap organisasi melihat keluar. Lingkungan yang dipengaruhi oleh faktor luar misalnya tingkat penerangan, kondisi ruangan, intensitas pencahayaan, keamanan dan penempatan yang tepat sesuai dengan kebutuhannya. Lousie (2002:56) menegaskan, "work environment is defined as the set of conditions under which work is peformed, these conditions include phisical, social, phychological, and enviromental factors". Lingkungan kerja adalah sebuah suasana kerja dimana suatu pekerjaan dilaksanakan. Yang dimaksud dengan lingkungan fisik adalah segala sesuatu yang ada dalam dunia ini yang bukan manusia, lingkungan psikis adalah pandangan kita terhadap situasi tempat kerja, dan lingkungan sosial adalah semua orang atau manusia lain yang mempengaruhi kita. Christopher (2009:294) mengemukakan, "work environment is defined as the phisical setting, the reward system, clarity about expectations and roles, agency in decision making, supervisor support, and communication. Dijelaskan bahwa lingkungan kerja itu adalah penataan ruangan fisik tempat bekerja, sistem penghargaan, kejelasaan peraturan, alat untuk mengambil keputusan, pendukung pengawasan, dan komunikasi.

Pendapat Robbins (2009:571) menyatakan, "an organization's environment is composed of situations or forces outside the organization that potentially affect the organization's performance". Lingkungan kerja adalah segala sesuatu yang berada diluar organisasi yang secara potensial mempengaruhi kinerja organisasi. Apabila lingkungan itu baik 
dan mendukung setiap kegiatan-kegiatan dari seorang pekerja maka dapat membantu keberhasilan menyelesaikan tugas atau pekerjaannya.

Seyfarth (2002:185)menjelaskan, "productive work environtment are those that enable employees to perform their jobs effectively and to experience psychological succes while doing". Lingkungan kerja yang produktif akan memungkinkan karyawan-karyawannya akan menampilkan pekerjaan mereka yang efektif dan memberikan pengalaman psikologis yang berhasil ketika bekerja. Kondisi lingkungan kerja yang berbeda pada setiap organisasi dapat memberikan tingkat kepuasan yang berbeda pula bagi karyawan, sehingga prestasi kerja dalam menyelesaikan tugas yang dibebankan padanya juga berbeda. Yang harus diusahakan untuk memperbaiki metode kerja dalam suatu organisasi atau tempat kerja yang lain adalah menjamin agar para karyawan dapat bekerja dan melaksanakan tugasnya dalam keadaan yang memenuhi persyaratan, sehingga mereka dapat melakukan tugasnya tanpa mengalami hambatan.

Swapna Kishore (2003:140) mengemukakan, "work environment is the set of conditions under which the people have to perform work and includes phisical, social, phychological and environmental factors". Lingkungan kerja adalah sebuah kondisi oleh seseorang untuk melakukan pekerjaan mencakup keadaan fisik, keadaan sosial dan keadaan psikologis serta faktor lingkungan lainnya.

Berdasarkan uraian di atas, dapat disintesiskan lingkungan kerja dalah kondisi di tempat kerja yang mempengaruhi terhadap keefektifan melaksanakan pekerjaan dengan indikator yang terdiri dari: penataan ruangan; fasilitas kerja; pencahayaan dan sirkulasi udara; perawatan kebersihan; hubungan antar pegawai; suasana kerja. 


\section{Kreativitas}

McShane (2008:240), "creativity is developing an original product, service, or idea that makes a socially recognized contribution". Kreativitas adalah mengembangkan produk asli, jasa, atau ide yang membuat kontribusi yang diakui secara sosial. Hal tersebut akan membutukan waktu dan inovasi untuk menjadikan suatu produk asli menjadi produk yang baru dengan cara yang unik. Debra (2009:231) menyatakan, "creativity is a process influenced by individual and organizational factors that results in the production of novel and useful ideas, products, or both". Kreativitas adalah suatu proses yang dipengaruhi oleh faktor individu dan organisasi yang menghasilkan produksi ide-ide baru dan berguna, produk, atau keduanya. Masters dan Wallace (2011:9-10) mendefinisikan kreativitas sebagai, "creativity is the tendency to generate or recognize ideas, alternatives, or possibilities that maybe useful in solving problems, people are problems solvers. Creativity is especially helpful in the workplace, where ivorkers face problems and must make decisions on a daily basis". Kreativitas adalah kecenderungan untuk menghasilkan ide-ide atau mengenali, alternatif, atau kemungkinan yang mungkin berguna dalam memecahkan masalah, berkomunikasi dengan orang lain, dan menghibur diri kita sendiri. Orang-orang kreatif adalah pemecah masalah. Sedangkan Mullins (2002:415) menyatakan pendapatnya, "creativity is the application of imaginative thought which results in innovative solutions to many problems". Kreativitas adalah aplikasi pemikiran imajinasi yang menghasilkan solusi inovatif untuk masalah yang banyak. Pemikiran yang imajinasi di terapkan dalam suatu produk sehingga dapat membuat solusi alternatif dari suatu permasalahan yang ada. Berbeda halnya dengan Jeff Degraff dan Katherine (2002:4-5) berpendapat bahwa, "creativity as a purposeful activity (or set of activities) that produces valuable products, services, prosess, or ideas that are better or new. The act of creativity can be performed by an individual, a group, or an organization, or all of these working together to produce a creative outcome, whittler innovation, profits, quality, knowledge, or some otter desired result". Kreativitas sebagai kegiatan yang bertujuan (atau sejumlah kegiatan) yang menghasilkan produk berharga, jasa, proses, atau ide yang lebih baik atau baru. Tindakan kreativitas dapat dilakukan oleh individu, kelompok, atau organisasi, atau semua bekerja sama untuk menghasilkan hasil yang kreatif, apakah inovasi, keuntungan, kualitas, pengetahuan, atau beberapa hasil yang diinginkan lainnya. Kreativitas merupakan penemuan atau asal usul setiap hal baru berupa produk, solusi, yang memiliki nilai. Kreativitas menekankan pada dua hal utama, yaitu "baru" dan "nilai". Kata "baru" berarti hal yang belum ada sebelumnya atau inovatif dari sudut pandang individu, komunitas atau masyarakat di wilayah tertentu. Kata "nilai" berarti manfaat yang dirasakan oleh individu, komunitas atau masyarakat di daerah tertentu.

Scott Isaksen (2011:6) menyatakan kreativitas sebagai " creativity is the process of generating unique products by transformation of existing products. These products must be unique only to the creator, and must meet the criteria of purpose and value established by the creator. ${ }^{\mathrm{n}}$ Kreativitas adalah proses menghasilkan produk yang unik dengan transformasi produk yang ada. Produk-produk ini harus unik hanya untuk sang pencipta, dan harus memenuhi kriteria tujuan dan nilai yang ditetapkan oleh sang pencipta.

Berdasarkan definisi konsep di atas dapat disintesiskan kreativitas adalah aktivitas individu untuk pemikiran yang baru dan unik dalam mengembangkan produk untuk mencapai tujuan yang telah ditetapkan dengan indikator: kontribusi yang diakui,

\footnotetext{
${ }^{1}$ Scott G Isaksen, Dorval, Treffinger, Creative Aprroaches To Problem Solving (United States Of America: Sage Publications, 2011), h. 6
} 
pengembangan produk asli menjadi lebih baru, upaya alternatif memecahkan masalah, dan solusi inovatif untuk suatu masalah.

\section{METODE PENELITIAN}

Penelitian menggunakan metode survey dengan pendekatan teknik analisis jalur. Penelitian ini dilakukan tiga bulan yaitu pada bulan Agustus sampai dengan Oktober 2013. Penelitian dilaksanakan di SMA Negeri yang berada di wilayah Sub Rayon Kota Bekasi. Populasi terjangkau penelitian ini sejumlah 236 guru. Sampel penelitian sebayak 149 orang. Analisa data untuk pengujian hipotesis akan dilakukan dengan menggunakan teknik analisis jalur, yaitu teknik yang diterapkan untuk menjelaskan pengaruh antara variabel-variabel penelitian. Sebelum dilaksanakan analisis jalur, uji signifikan regresi dan uji linearitas regresi sebagai prasyarat uji statistik dilakukan pengujian penormalan data dari masing-masing variabel penelitian dengan Uji-Liliefors, Statistik inferensial digunakan untuk menguji hipotesis tentang pengaruh antar variabel dengan menggunakan tehnik analisis jalur.

\section{HASIL DAN PEMBAHASAN \\ Pengaruh Lingkungan kerja terhadap Stres}

Hasil analisis korelasi sederhana antara lingkungan kerja dengan stres diperoleh koefisien korelasi sebesar -0,591 dan koefisien jalur -0,434. Dengan demikian pengaruh lingkungan kerja dengan stres negatif, artinya semakin baik lingkungan kerja, diharapkan terjadi penurunan stres guru.

Dikaitkan dengan teori tentang pengaruh lingkungan kerja terhadap stres seperti yang dinyatakan oleh Jennifer (2012:257), "uncomfortable working conditions are another source of stress for groups and entire organizations. Excessive noise, temperature extremes, and poor designed office equipment and machinery can be very stressful when employees are exposed to them day in and day out". Kondisi kerja tidak nyaman adalah sumber sties bagi kelompok dan organisasi secara keseluruhan. Kebisingan yang berlebihan, suhu ekstrim, dan peralatan kantor yang buruk dirancang dan mesin bisa sangat menegangkan ketika karyawan dihadapkan kepada mereka hari demi hari. Kondisi tersebut membuat para pegawai menjadi tidak berkonstrasi terhadap tujuan organisasi. Sanaa halnya dengan Robbins (2009:644) nienyatakan pengaruh lingkungan kerja terhadap stress, "task demands related to a person's job. They include the design of the job (its degrees of autonomy, task variety, degree of automation), working conditions, and the physical work layout. Assembly lines can put pressure on people when they perceive the line's speed to be excessive. Working in an overcrowded room or a visible location where noise and interruptions are constant can increase anxiety and stress". Bekerja di ruang penuh sesak atau lokasi yang terlihat di mana kebisingan dan gangguan yang konstan dapat meningkatkan kecemasan dan stres.

Dari pembahasan di atas, terdapat pengaruh negatif lingkungan kerja terhadap stres guru. Semakin baik lingkungan kerja yang diberikan kepada guru, maka semakin rendah pula stres yang akan terjadi. 


\section{Pengaruh Kreativitas terhadap Stres}

Hasil analisis korelasi sederhana antara kreativitas dengan stres diperoleh koefisien korelasi sebesar - 0,549 dan koefisien jalur - 0,358. Dengan demikian pengaruh kreativitas terhadap stres adalah negaif. Semakin baik kreativitas diharapkan semakin rendah pula tingkat stres guru.

Dikaitkan dengan teori tentang pengaruh kreativitas terhadap stress, Kreitner (2008:556) menyatakan pengaruh kreativitas terhadap stres, "the most common examples of individual stressors are job demands, work overload, role conflict, role ambiguity, everyday hassles, perceived control over events occurring in the work environment, and job characteristics. Losing one's job is another important individual level stressors. Job loss is a very stressful event that is associated with decreased psychological and physical well-being, finally, sleep-related issues are important stressors. Research shows that most people need about seven hours of sleep per night and that alertness, energy, performance, creativity, and thinking are related to how refreshed an employee feels when starting his/lier workday". Contoh yang paling umum dari stres individu adalah tuntutan pekerjaan, kelebihan beban kerja, konflik peran, ketidakjelasan peran, kerepotan sehari-hari, merasakan tekanan peristiwa yang terjadi di lingkungan kerja, dan karakteristik pekerjaan. Kehilangan pekerjaan merupakan salah satu faktor penting dari stres individu. Kehilangan pekerjaan adalah peristiwa yang sangat menegangkan yang berhubungan dengan penurunan psikologis dan kesejahteraan fisik. Akhirnya, masalah tidur-terkait stres penting. Penelitian menunjukkan bahwa kebanyakan orang membutuhkan sekitar tujuh jam tidur per malam dan kewaspadaan, energi, kinerja, kreativitas, dan pemikiran terkait dengan bagaimana seorang karyawan merasa segar ketika memulainya hari kerjanya.

Atas dasar uraian tersebut, terdapat pengaruh negatif kreativitas terhadap stres. Dengan kata lain, semakin tinggi kreativitas maka semakin rendah pula stres yang akan terjadi.

\section{Pengaruh Lingkungan kerja terhadap Kreativitas}

Hasil analisis korelasi sederhana antara lingkungan kerja dengan kreativitas diperoleh koefisien korelasi sebesar 0,439 dan koefisien jalur 0,439. Dengan demikian pengaruh lingkungan kerja terhadap kreativitas sangat tinggi dan positif. Semakin baik lingkungan kerja diharapkan semakin tinggi pula kreativitas.

Dikaitkan dengan teori tentang pengaruh lingkungan kerja terhadap kreativitas seperti yang dinyatakan oleh Kreitner (2008:364), menyatakan adanya pengaruh lingkungan kerja terhadap kreativitas sebagai berikut, "employees eventually received monetary wizards for any suggestions that passed all five phases of this process. This research underscores the conclusion that creativity can be enhanced by effectively managing the creativity proces and by fostering a positive and supportive work environment". Seorang pegawai akhirnya menerima penghargaan untuk setiap saran yang melewati kelima tahap dari proses ini. Penelitian ini menggarisbawahi kesimpulan bahwa kreativitas dapat ditingkatkan dengan efektif mengelola proses kreativitas dan dengan memupuk lingkungan kerja yang positif dan mendukung. Lingkungan kerja yang baik dan kondusif memberikan peluang untuk meningkatkan kualitas kerja pegawai tersebut.

Dari pembahasan di atas, terdapat pengaruh positif lingkungan kerja terhadap kreativitas. Artinya semakin kondusif lingkungan kerja, maka semakin tinggi pula kreativitas yang akan terjadi. 


\section{PENUTUP}

\section{Kesimpulan.}

Berdasarkan hasil analisa dan kajian dari penelitian ini dapat disimpulkan bahwa: (1) Lingkungan kerja berpengaruh langsung negatif terhadap stres guru SMA Negeri Sub Rayon 1 Kota Bekasi. Lingkungan kerja yang baik akan mengakibatkan penurunan stres; (2) Kreativitas berpengaruh langsung negatif terhadap stres guru SMA Negeri Sub Rayon 1 Kota Bekasi. Kreativitas yang tinggi akan mengakibatkan penurunan stres guru; (3) Lingkungan kerja berpengaruh langsung positif terhadap Kreativitas guru SMA Negeri Sub Rayon 1 Kota Bekasi. Lingkungan kerja yang kondusif akan mengakibatkan peningkatan kreativitas.

\section{Saran}

Berdasarkan hasil penelitian upaya untuk meningkatkan stres guru dapat dilaksanakan melalui peningkatan kualitas lingkungan kerja yang kondusif dan kreativitas yang tinggi. Upaya tersebut memerlukan dukungan semua pihak yang terlibat dalarn penyelengaraan pendidikan di sekolah. Berikut dikemukakan beberapa saran khususnya kepada pihak-pihak terkait sehubungan dengan upaya meminimalkan stres guru: 1)Lingkungan sekolah diupayakan menjadi lingkungan yang ramah dan kondusif buat para guru, sehingga guru nyaman dalam bekerja; 2) Guru diharapkan memiliki kreativitas yang tinggi; 3) Kepala sekolah sebagai pemimpin hendaknya mempunyai kompetensi yang harus dikuasai sebagai dasar untuk menciptakan lingkungan kerja yang baik bagi setiap personil yang ada di sekolah. Lingkungan kerja guru memberikan dampak penurunan terhadap stres, sehingga peningkatkan mutu pendidikan dapat tercapai; 4) Lingkungan kerja yang melibatkan guru dapat menumbuhkan tanggung jawab, kerja sarna dan loyalitas dalam melaksanakan tugas dan aturan-aturan yang telah disepakati; 5) Keteladanan adalah cara yang paling efektif untuk mendapatkan hasil yang maksimal; 6) Hasil penelitian tentang stres tenaga guru memerlukan penelitian lebih lanjut. Disamping itu perlu juga dilakukan penelitian untuk mengemukakan pendekatan atau cara praktis dalam rangka meminimalkan tingkat stres guru. 


\section{DAFTAR RUJUKAN}

Christopher T, Cross, Taniesha A.Woods, Heidi S. Mathematics Learning in Early Childhood. United State of America: National Academy of Science, 2009.

Debra L.Nelson. Organizational Behavior. USA: South-Western Cengage, 2009.

Learning James C. Kaufman, Robert J. Sternberg. The International Handbook of Creativity, New York: Cambridge University Press, 2006.

Jeff DeGraff, Katherine A. Lawrence. Creativity at Work, United States Of America: Jhon Wiley \& Sons, 2002.

Jennifer M.George, Gareth R.Jones. Understanding And Managing Organizational Behavior. New Jersey : Prentice Hall Pearson, 2012.

John T. Seyfarth. Human Resources Management for Effective Schools. Boston: Allyn\& Bacon, 2002.

Kreitner/Kinicki. Organizational Behavior. New York: McGraw-Hill, 2008.

Laurie J. Mullins. Management and Organizational Behaviour, England: Pearson Education Limited, 2002.

Masters, Wallace. Personal Development For Life and Work. USA: Southwestern Cengage Learning, 2011.

McShane,Von Glinow. Organizational Behavior. New York: McGraw-Hill Irwin, 2008.

Scott G Isaksen, Dorval, Treffinger. Creative Aprroaclies To Problem Solving. United States Of America: Sage Publications, 2011.

Slocum/Hellriegel. Fundamentals of Organizational Behavior. USA: Thomson South Western, 2007.

Stephen Robbins, Timothy A.Judge. Organizational Behavior 13th Edition. United State of America: Pearson Prentice Hall, 2009.

Swapna Kishore, Rajesh Naik. ISO 9001: For Software Organizations. New Delhi: Tata Me Grwa-Hill, 2003 
